В.М. Совенко, Н.М. Храновська, О.В. Скачкова, А.В. Ганул, Л.В. Бороров, Б.О. Борисюк, В.Е. Орел, В.А. Ганул, А.І. Шевченко, В.В. Величко, І.І. Фірчук

\title{
Лікування пацієнтів з метастазами раку нирки в легені за допомогою дендритноклітинної аутовакцини
}

\author{
Національний інститут раку, Київ \\ Одержано 09.11.2019 \\ Прийнято до друку 10.12.2019 \\ DOI:10.32471/clinicaloncology.2663-466X.36-4.26655
}

\begin{abstract}
Вступ. У сучасному світі активно вивчаються можливості застосування таргетної терапії та імунотерапії в лікуванні раку нирки. Відкрито нові підходи до створення ефективних стимуляторів протипухлинної імунної відповіді для підвищення ефективності вакцинотерапії у хворих на метастатичний рак нирки. Мета. Дослідити безпеку та ефективність застосування дендритноклітинної (ДК) аутовакцини у хворих на рак нирки. Об'єкт і методи дослідження. У науково-дослідному відділенні пухлин органів грудної порожнини Національного інституту раку нами було виконано дослідження ефективності застосування ДК-аутовакцини у хворих на рак нирки з метастазами в легені. Під час виконання роботи було оцінено безпеку та токсичність лікування ДК-аутовакциною хворих на рак нирки. Комплексним методом з включенням післяопераційного введення ДК-аутовакцини проліковано 10 пацієнтів з метастазами раку нирки в легені. Проведено аналіз ефективності та безпеки застосування ДК-аутовакцини. Оцінено можливості подальшого застосування ДК-аутовакцини в комплексному лікуванні хворих з метастазами раку нирки в легені. Результати. Медіана виживаності в основній (n=10) групі пацієнтів з метастазами раку нирки в легені, які були прооперовані та післяопераційно отримували ДК-аутовакцину, становила 45,1 міс. Медіана виживаності в контрольній (n=10) групі хворих становила 39,3 міс (різниця статистично недостовірна; р=0,708). Загальна 5-річна виживаність хворих в основній групі становила 78,7\% порівняно з 69,1 \% у контрольній групі. Безрецидивна 5-річна виживаність у пацієнтів з метастазами раку нирки в легені становила 69,4 і 60,4\% в основній і контрольній групах відповідно (різниця статистично недостовірна; р=0,605). Як видно з результатів, застосування ДКаутовакцини в комплексному лікуванні хворих на рак нирки продемонструвало тенденцію до підвищення виживаності, однак необхідно оцінити більшу кількість спостережень. Висновки. Отримані дані про тенденцію до покращення виживаності дозволяють планувати подальші дослідження в цьому напрямку. Проведення ДК-аутовакцинотерапії, спрямоване на підвищення ефективності лікування пацієнтів з метастазами раку нирки в легені, не супроводжується токсичними проявами та побічними явищами.
\end{abstract}

Ключові слова: дендритноклітинна аутовакцина; рак нирки; метастази; легені.

\section{ВСТУП}

Лікування метастатичного раку нирки є актуальною проблемою сучасної онкології. Проводиться багато досліджень з вивчення можливостей поліпшення результатів лікування онкохворих з цією патологією за допомогою таргетної терапії та імунотерапії [1-3]. Надії на можливості біотерапевтичних методів в лікуванні злоякісних пухлин, і саме раку нирки, пов'язані зі значними успіхами в галузі генетики, молекулярної біології, імунології, клітинної інженерії [4-6]. Сучасні уявлення про імунологію пухлини, механізми канцерогенезу і регуляцію пухлинного росту в останні роки значно поглиблено [7-9]. Отримано підтвердження перспективності розвитку активної специфічної імунотерапії [10-12]. Відкрито нові підходи до створення ефективних імуногенних засобів і неспецифічних стимуляторів протипухлинноїімунної відповіді, розширено можливості моніторингу функціонування окремихланок імунних реакцій $[13,14]$. Триває пошук оптимальних режимів та циклічності введень для підвищення ефективності вакцинотерапії у хворих на метастатичний рак нирки.

\section{ОБ 'ЄКТ І МЕТОДИ ДОСЛІДЖЕННЯ}

У науково-дослідному відділенні пухлин органів грудної порожнини Національного інституту раку (НIР) нами було виконано дослідження ефективності застосування ДК-аутовакцини у хворих на рак нирки з метастазами в легені. При виконанні роботи було оцінено безпеку та токсичність лікування ДК-аутовакциною хворих на рак нирки. Було відстежено зміни імунологічних показників у процесі лікування. Комплексним методом з включенням післяопераційного введення ДК-аутовакцини проліковано 10 пацієнтів з метастазами раку нирки в легені.

Було проаналізовано дані 20 хворих на рак нирки з метастазами в легені, які перебували на лікуванні в 2013-2019 рр. у науководослідному відділенні пухлин органів грудної порожнини Національного інституту раку: 10 хворих в основній та $10-$ у контрольній групі.
Середній вік хворихстановив 64,5 років. Документацію, інформовані згоди та всі матеріали було надано на розгляд комітету з етики і отримано схвалення. У всіх пацієнтів отримано письмову згоду на участь у дослідженні, при цьому було поінформовано про мету, завдання і методи дослідження, зроблено застереження про можливий ризик. У співпраці зі співробітниками науково-дослідних лабораторій експериментальної онкології, медичної фізики та біоінженерії було виготовлено оригінальну ДК-аутовакцину індивідуально для кожного введення.

ДК-аутовакцину було розроблено в НІР і захищено патентами на винахід. Дендритні клітини для виготовлення аутовакцини отримували 3 моноцитів периферичної крові хворих шляхом їх інкубації в живильному середовищі RPMI 1640 упродовж 8 діб у присутності гранулоцит-моноцитарного колонієстимулюючого фактора, інтерлейкіну-4, інтерферону- $\gamma$ і ліпополісахаридів.

Для отримання пухлиноасоційованих антигенів, 3 метою навантаження ними дендритних клітин, використовували біоінженернутехнологію механохімічної гетерогенізаціїліофілізованих пухлинних клітин за допомогою мікровібромлина з наступним додаванням отриманихантигенів до культури вирошуваних дендритних клітин на 6-ту добу культивування в концентрації 0,05 мг/мл.

Виготовлення ДК-аутовакцини проводилося в науководослідній лабораторії експериментальної онкології НІР. Хворі отримували стандарний комплекс лікування: оперативне втручання та в разі необхідності застосування неоад'ювантної таргетної терапії. Далі хворих було розділено на 2 групи. Комплекс лікування розрізнявся за застосуванням ДК-аутовакцини: групи з використанням і без використання ДК-аутовакцини.

Проведено аналіз ефективності та безпеки застосування ДКаутовакцини, здійснено моніторинг імунологічних показників. Отримані результати використані для визначення можливості подальшого застосування ДК-аутовакцини в комплексному лікуванні пацієнтів з метастазами раку нирки в легені. Усім хворим препарат вводили внутрішньовенно, розводили у 50 мл роз- 
Таблиця 1. Протокол лікування пацієнтів 3 метастазами раку нирки в легені основної групи

\begin{tabular}{|c|c|c|c|c|c|c|}
\hline \multirow{2}{*}{ Процедура } & \multirow{2}{*}{$\begin{array}{c}\text { До введення } \\
\text { ДК-аутовакцини }\end{array}$} & \multicolumn{5}{|c|}{ День } \\
\hline & & 14-й ( \pm 7$)$ & 52-й ( \pm 7$)$ & $90-и ̆( \pm 7)$ & 128-й ( \pm 7$)$ & 164-й ( \pm 7$)$ \\
\hline Інформована згода & $\mathrm{X}$ & & & & & \\
\hline Реєстрація даних про хірургічне втручання & $\mathrm{X}$ & & & & & \\
\hline Перевірка критеріїв включення/невключення в дослідження & $\mathrm{X}$ & & & & & \\
\hline Історія захворювання пацієнтів & $\mathrm{X}$ & & & & & \\
\hline Інформація про таргетну терапію & $\mathrm{X}$ & & & & & \\
\hline Фізикальне обстеження & $\mathrm{X}$ & $X$ & $X$ & $X$ & $X$ & $\mathrm{X}$ \\
\hline Оцінка статусу за шкалою Східної об'єднаної групи & $\mathrm{X}$ & $X$ & $\mathrm{X}$ & $X$ & $\mathrm{X}$ & $\mathrm{X}$ \\
\hline онкологів (Eastern Cooperative Oncology Group - ECOG) & & & & & & \\
\hline Реєстрація негативних проявів & $\mathrm{X}$ & $X$ & $X$ & $X$ & $\mathrm{X}$ & $\mathrm{X}$ \\
\hline Реєстрація супутніх захворювань & $\mathrm{X}$ & & & & & \\
\hline Інформація про застосування супутніх препаратів (за попередні 7 днів) & $\mathrm{X}$ & & & & & \\
\hline Рентгенографія органів грудної порожнини & & $X$ & & $X$ & & $\mathrm{X}$ \\
\hline Комп'ютерна томографія & & & $\mathrm{X}$ & & $X$ & \\
\hline Лабораторні дослідження & $\mathrm{X}$ & $X$ & & $X$ & & $\mathrm{X}$ \\
\hline Імунологічні дослідження & $\mathrm{X}$ & $\mathrm{X}$ & $\mathrm{X}$ & $X$ & $\mathrm{X}$ & $\mathrm{X}$ \\
\hline Оцінка загальної виживаності & & Увесь пе & ріод спостер & еження & & \\
\hline Оцінка безрецидивної виживаності & & Увесь пе & ріод спостер & еження & & \\
\hline Оцінка медіани загальної виживаності & & Увесь пе & ріод спостер & еження & & \\
\hline
\end{tabular}

чину Рінгера, 1 раз на місяць; в середньому за ін'єкцію вводили $(4,5 \pm 0,35) \cdot 10^{6}$ дендритних клітин. Пацієнтам проводили 5 щомісячних введень. Імунологічний моніторинг здійснювався протягом 6 міс.

У хворих, у яких упродовж першого року були відсутні ознаки прогресування захворювання, продовжували лікування ДКаутовакциною: на 2-му році здійснювалося 5 щомісячних введень іпісля 6-місячної перерви - ще 5 щомісячних введень на 3-му році післяопераційного періоду. Пацієнти перебували під подальшим амбулаторним спостереженням - один раз на 3-6 міс проводилася комп'ютерна томографія органів грудної порожнини.

Дані про розподіл пацієнтів з метастазами раку нирки в легені за віком, статтю, стадіями, таргетною терапією і за гістологічним типом наведено в табл. 2.

Розподіл хворих залежно від обсягу оперативного втручання представлено в табл. 3.

У процесілікування хворихзадопомогоюДК-аутовакцини оцінювали безпеку їі застосування. Після введення ДК-аутовакцини здійснювався моніторинг стану хворих для виявлення можливих побічних реакцій. Контроль проводили відповідно до критеріїв токсичності, рекомендованих Всесвітньою організацією охорони здоров'я. Основні життєві параметри (загальний стан, пульс, артеріальний тиск) вимірювали через 10, 30 і 60 хв після кожного введення вакцини. Особливу увагу приділяли місцевим шкірним реакціям, лихоманці, гастроінтестинальній і гематологічній змінам, а також функції печінки, нирок і нервової системи.

На теперішній час продовжується обробка даних та оцінка імунної відповіді в процесі проведення ДК-імунотерапії.

Отримані результати оцінено за методами статистичного аналізу. Статистичне узагальнення результатів здійснено з використанням пакета програм Excel 2007 та STATISTICA 8, оцінку статистичної значимості різниці між групами проводили за непараметричним критерієм Манна - Уітні. Для оцінки онкологічної

Таблиця 2. Розподіл пацієнтів з метастазами раку нирки в легені за статю, кількістю циклів поліхіміотерапії та гістологічним типом

\begin{tabular}{lcc}
\hline \multicolumn{1}{c}{ Параметр } & \multicolumn{2}{c}{ Група хворих, $\mathbf{n}(\%)$} \\
\cline { 2 - 3 } & Основна, $\mathbf{n = 1 0}$ & Контрольна, $\mathbf{n = 1 0}$ \\
\hline Середній вік, років & 65,7 & 63,3 \\
Чоловіки/жінки & $6(60,00) / 4(40,00)$ & $7(70,00) / 3(30,00)$ \\
I/ІІІ стадія & $7(70,00) / 3(30,00)$ & $8(80,00) / 2(20,00)$ \\
Призначення таргетної терапії & $6(60,00) / 4(40,00)$ & $9(90,00) / 1(10,00)$ \\
(пазопаніб), так/ні & & \\
Світлоклітинний рак/ папілярний рак & $9(90,00) / 1(10,00)$ & $9(90,00) / 1(10,00)$ \\
\hline
\end{tabular}

Таблиця 3. Розподіл пацієнтів з метастазами раку нирки в легені залежно від обсягу оперативного втручання

\begin{tabular}{lcccc}
\hline \multirow{2}{*}{ обсяг операції } & \multicolumn{4}{c}{ Група хворих, $\mathbf{n ~ ( \% ) ~}$} \\
\cline { 2 - 5 } & Основна, $\mathbf{n = 1 0}$ & Контрольна, $\mathbf{n = 1 0}$ \\
\hline Атипова резекція одностороння & 6 & 60,00 & 5 & 50,00 \\
Атипові резекції двосторонні & 2 & 20,00 & 3 & 30,00 \\
Лобектомія & 1 & 10,00 & 0 & 0,00 \\
$\begin{array}{l}\text { Видалення метастатичних се- } \\
\text { редостінних лімфатичних вузлів }\end{array}$ & 1 & 10,00 & 2 & 20,00 \\
Усього & 10 & 100,00 & 10 & 100,00 \\
\hline
\end{tabular}

виживаності визначали загальну, безрецидивну та канцерспецифічну виживаність за кривими Каплана - Мейєра.

Усі цитометричні дослідження виконані на приладі FACSCalibur (Becton Dickinson, США) з використанням програми CellQuest-PRO для набору та аналізу даних.

Оцінка клінічного ефекту ДК-аутовакцини поєднувалася з лабораторною оцінкою рівня специфічної протипухлинної імунної відповіді.

Слід зазначити, що найбільш виражені зміни в стані клітинноопосередкованої імунної відповіді під дією ДК-аутовакцини спостерігаються після 3-4 шомісячних введень.

Відомо, що імунологічна відповідь на пухлинний антиген, які на будь-які антигени, складається з комплексу процесів, у яких взаємодіють ефекторні і регуляторні механізми, тим чи іншим способом задіяні на різних етапах специфічної і неспецифічної клітинної імунної відповіді. Тому для забезпечення максимальної ефективності ДК-аутовакцина впливала на різні ланки імунітету як на неспецифічну, основою якої є функціонування натуральних кілерних клітин і макрофагів, так і специфічну, переважно на їі Т-клітинну ланку. Визначення рівня розвитку антигенспецифічної Т-клітинної імунної відповіді на пухлинний антиген вважається базовим показником в оцінці та прогнозуванні клінічної відповіді на проведену активну специфічну імунотерапію.

\section{РЕЗУЛЬТАТИ}

Показники загальної виживаності пацієнтів зметастазами раку нирки в легені за 5-річний період спостереження з використанням (основна група, $\mathrm{n}=10$ ) ібез використання (контрольна група, $\mathrm{n}=10$ ) ДК-аутовакцини наведено нижче.

Медіана виживаності в основній $(\mathrm{n}=10)$ групі пацієнтів з метастазами раку нирки в легені, які були прооперовані та післяопераційно отримували ДК-аутовакцину, становила 45,1 міс. Медіана виживаності в контрольній (n=10) групі хворих становила 39,3 міс (різниця статистично недостовірна; $\mathrm{p}=0,708$ ).

Загальна 5-річна виживаність хворих в основній групі становила 78,7\% порівняно з 69,1\% - у контрольній групі. Безрецидивна 5-річна виживаність у пацієнтів з метастазами раку нирки в легені становила 69,4 i 60,4\% в основній і контрольній групах відповідно (різниця статистично недостовірна; $\mathrm{p}=0,605$ ). Як видно з результатів, застосування ДК-аутовакцини в комплексному лікуванні пацієнтів з раком нирки продемонструвало тенденцію до підвищення виживаності, однак необхідно оцінити більшу кількість спостережень.

Токсичних ускладнень і виражених побічних реакцій при застосуванні ДК-аутовакцини не було виявлено. За період проведення дослідження не відмічено інших негативних проявів, окрім гіпертермії до $37,5-38,0{ }^{\circ} \mathrm{C}$ у $3(30,0 \%)$ хворих, яка минала через добу самостійно.

\section{ВИСНОВКИ}

Отримані дані стосовно тенденціїдо підвищення виживаності дозволяють планувати подальші дослідження в цьому напрямку. 
Проведення ДК-аутовакцинотерапії, спрямоване на підвищення ефективності лікування пацієнтів з метастазами раку нирки в легені, не супроводжується токсичними проявами та побічними явищами.

Успішне застосування ДК-аутовакцини дозволить зменшити кількість рецидивів та випадків віддаленого метастазування у пацієнтів з метастазами раку нирки в легені, забезпечить можливість економії фінансових ресурсів, порівняно з витратами на проведення таргетної терапії.

\section{СПИСОК ВИКОРИСТАНОЇ ЛІТЕРАТУРИ}

1. Jemal, A., Siegel, R., Xu, J., Ward, E. \& Forman, D. (2011). Cancer statistics. CA: A Cancer Journal for Clinicians, 61(2), 69-90. doi: 10.3322/caac.20107

2. Altekruse, S. F., Kosary, C. L., Krapcho, M., Neyman, N., Aminou, R., Waldron, W., ...Cronin, K. (2010). Surveillance, Epidemiology, and End Results Cancer Statistics Review, 1975-2007. Bethesda: National Cancer Institute. Retrieved from https://seer.cancer.gov/archive/csr/1975 2007

3. American Cancer Society. (2011). Cancer Facts \& Figures 2011. Atlanta: American Cancer Society.

4. Siegel, R., Ward, E., Brawley, O., \& Jemal, A. (2011). Cancer statistics, 2011. The impact of eliminating socioeconomic and racial disparities on premature cancer deaths. Cancer Journa Clinic, 61(4), 212-236. doi: 10.3322/caac.20121

5. Гриневич, Ю. А., \& Храновская, Н. Н. (2003). Дендритные клетки и перспективы ихиспользования в иммунотерапии больныхсо злокачественными новообразованиями (обзор литературы). Журнал АМН Украины, 9(4), 736-753.

6. Космачева, С. М., Суренский, С. В., Белевцев, М. В., \& Потапнев, М. П. (2006) Характеристика дендритных клеток, генерированных из моноцитов периферической крови человека под действием ИФН-а. Иммунопатология, аллергология, инфектология, 3, 6-12.

7. Мосиенко, В. С., \& Куртсеитов, Л. К. (2010). Интегральные подходы к лечению опухолевой болезни. Киев: Школьный мир.

8. Danilov, A. O., Larin S. S., Danilova, A. B., Moiseenko, V. M., Balduyeva, I. A. Kiselev, S. L., ... Hanson, K. P. (2004). An improved procedure for autologous gene-modified vaccine preparation for active specific immunotherapy of disseminated solid tumors. Вопрось vасcine preparation for active

9. Щекина, Л. А., Балдуева, И. А., \& Моисеенко, В. М. (2003). Динамика иммунологических показателей в процессе активной специфической иммунотерапии больных с солидными опухолями. Тезисы научно-практической конференции «Проблемы онкоиммунологии: научные и прикладные аспекты». Онкология, 5(2), 176.

10. Данилова, А. Б. Данилов, А. О., Балдуева, И. А. \& Моисеенко, В. М. (2008). Изучение механизмов «уклонения» клеток солидных опухолей от иммунного контроля в контексте противоопухолевой терапии. Объединенный иммунологический форум. в контексте противоопухолевой терапии. Объединенный
Санкт-Петербург. Медицинская иммунология, 2(11), 306.

11. Гриневич, Ю. А., \& Югринова, Л. Г. (2015). Маркеры опухолевого роста. Київ: Здоров'я.

12. Marks, J. L., Broderick, S., Zhou, Q., Chitale, D., Li, A. R., Zakowski, M. F., ... Pao, W. (2008). Prognostic and therapeutic implications of EGFR and KRAS mutations in resected lung adenocarcinoma. Journal of Thoracic Oncology, 3(2), 111-116. doi: 10.1097/JTO.0b013e318160c607

13. Коростелев, С. А. (2003). Противоопухолевые вакцины. Современная онкология, 5(4), 160-169.

14. Steinman, R. M. \& Banchereau, J. (2007). Taking dendritic cells into medicine. Nature, 449(7161), 419-426. doi: 10.1038/nature06175

\section{Лечение пациентов с метастазами рака почки в легкие при помощи дендритноклеточной аутовакцины}

В.М. Совенко, Н.Н. Храновская, О.В. Скачкова, А.В. Ганул,

Л.В. Бороров, Б.О. Борисюк, В.Э. Орел, В.А. Ганул, А.И. Шевченко,

В.В. Величко, И.И. Фирчук

Национальный институт рака, Киев

Введение. В современном мире активно изучаются возможности применения таргетной терапии и иммунотерапии в лечении рака почки. Открыты новые подходы к созданию эффективных стимуляторов противоопухолевого иммунного ответадля повышения эффективности вакцинотерапии у больных метастатическим раком почки. Цель. Исследовать безопасность и эффективность дендритноклеточной (ДК) аутовакцины у больных раком почки. Объект и методы исследования. В научно-исследовательском отделении опухолей органов грудной полости Национального института рака нами было выполнено исследование эффективности применения ДК-аутовакцины у больных раком почки с метастазами в легкие. Во время выполнения работы были оценены безопасность и токсичность лечения ДК-аутовакциной больных раком почки. Комплексным методом с включением послеоперационного введения ДК-аутовакцины пролечены 10 пациентов с метастазами рака почки в легкие. Проведен анализ эффективности и безопасности применения ДК-аутовакцины. Оценены возможности дальнейшего применения ДК-аутовакцины в комплексном лечении больных с метастазами рака почки в легкие. Результаты. Медиана выживаемости в основной $(n=10)$ группе пациентов с метастазами рака почки в легкие, которые были прооперированы и послеоперационно получали ДК-аутовакцину, составила
45,1 мес. Медиана выживаемости в контрольной $(\mathrm{n}=10)$ группе больных составляла 39,3 мес (разница статистически недостоверна, $\mathrm{p}=0,708)$. Общая 5-летняя выживаемость больных в основной группе составила $78,7 \%$ по сравнению с $69,1 \%$ - в контрольной группе. Безрецидивная 5-летняя выживаемость у пациентов с метастазами рака почки в легкие составила 69,4 и 60,4\% в основной и контрольной группах соответственно (разница статистически недостоверна, $p=0,605$ ). Как видно из результатов, применение ДК-аутовакцины в комплексном лечении больных раком почки показало тенденцию к повышению выживаемости, однако необходимо оценить большее количество наблюдений. Выводы. Полученные данные о тенденции к улучшению выживаемости позволяют планировать дальнейшие исследования в этом направлении. Проведение ДК-аутовакцинотерапии, направленное на повышение эффективности лечения пациентов с метастазами рака почки в легкие, не сопровождается токсическими проявлениями и побочными явлениями.

Ключевые слова: дендритноклеточная аутовакцина; рак почки; метастазы; легкие.

\section{Treatment of renal cell cancer with metastases} in lung with dendritic cell auto-vaccine

V.M. Sovenko, N.M. Khranovska, O.V. Skachkova, A.V. Hanul, L.V. Bororov, B.O. Borisyuk, V.E. Orel, V.A. Hanul, A.I. Shevchenko, V.V. Velichko, I.I. Firchuk National Cancer Institute, Kyiv

Summary. Introduction. In the modern world, the possibility of using targeted therapy and immunotherapy in the treatment of renal cell cancer is being actively explored. New approaches to create effective antitumor immune response stimulators have been discovered to improve the effectiveness of vaccine therapy in patients with metastatic renal cell cancer. Goal. To investigate the safety and efficacy of using dendritic cell (DC) auto-vaccine in renal cell cancer patients. Object and methods of research. In the Research Department of Tumors of the Thoracic Cavity of the National Cancer Institute, we conducted a study of the effectiveness of the use of DC auto-vaccine in patients with renal cell cancer with lung metastases. In the course of our work, we evaluated the safety and toxicity of treatment with DC auto-vaccine of cancer patients with renal cell cancer. The complex method with the inclusion of postoperative injection of DC auto-vaccine treated 10 patients with metastases of renal cell cancer in the lung. The effectiveness and safety of the use of DC auto-vaccine was analyzed. Possibilities for further use of DC auto-vaccine in the complex treatment of patients with renal cell cancer with metastases in the lung were evaluated. Results. The median survival in the main $(n=10)$ group of patients with renal cell cancer with metastases in the lung who underwent postoperative and postoperative DC auto-vaccine was 45.1 months. The median survival in the control $(n=10)$ group of patients was 39.3 months (the difference was not statistically significant; $p=0.708$ ). The overall five-year survival of patients in the main group was $78.7 \%$, compared with $69.1 \%$ in the control group. Recurrent five-year survival in patients with renal cell cancer metastases to the lung was 69.4 and $60.4 \%$ in the main and control groups, respectively (difference statistically unreliable; $\mathrm{p}=0.605$ ). As can be seen from the results, the use of DC auto-vaccine in the complex treatment of patients with renal cell cancer has shown a tendency to improve survival, but more observations need to be evaluated. Conclusions. The data obtained on the tendency to improve survival allow us to plan further studies in this direction. Carrying out DC auto-vaccination aimed at improving the effectiveness of the treatment of patients with metastases of renal cell cancer in the lung is not accompanied by toxic manifestations and side effects.

Key words: dendritic cell auto-vaccine; renal cell cancer; metastases; lung.

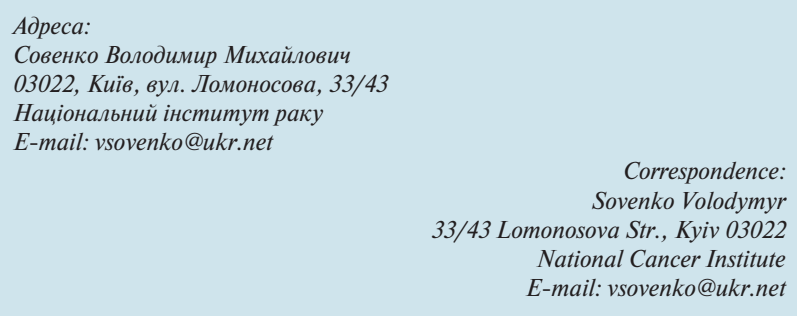

